\title{
NÁPOLES: UMA VIAGEM AOS TEMAS URBANOS DE WALTER BENJAMIN
}

\author{
Beatriz Salgado Cardoso de Oliveira ${ }^{1}$
}

\section{Introdução}

\begin{abstract}
Em suas remotas páginas consta que os animais se dividem em (a) pertencentes ao Imperador, (b) embalsamados, (c) amestrados, (d) leitões, (e) sereias, (f) fabulosos, (g) cães soltos, (h) incluídos nesta classificação, (i) que se agitam como loucos, (j) inumeráveis $(\mathrm{k})$ desenhados com um finíssimo pincel de pêlo de camelo, (l) (...) (Jorge Luis Borges).
\end{abstract}

A cidade se apresenta como tema recorrente e muitas vezes central nos trabalhos de Walter Benjamin que, com elas, teve uma "sutil, aguda e fantasmagórica relação" (Sontag, 1986: 87). Não obstante, o valioso espólio intelectual deste autor não se faz suficientemente presente como obra de referência para os atuais estudos urbanos. Como argumenta Michael Keith:

$\mathrm{Na}$ tentativa de contar a história de como as pessoas procuraram teorizar a vida social e econômica das cidades, o nome de Walter Benjamin está geralmente ausente do que podemos nos referir, de forma mais solta, como o cânone dos estudos urbanos. Isso não deveria acontecer (Keith, 2003: 410, tradução da pesquisadora) ${ }^{2}$.

De fato, apesar da existência de um número considerável de estudos sobre seus

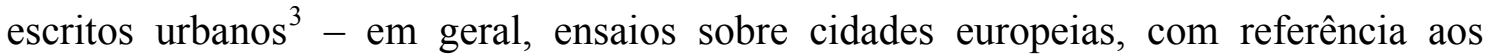
séculos XIX e XX - a obra de Benjamin não é considerada mainstream na antropologia ou sociologia urbanas ${ }^{4}$.

\footnotetext{
${ }^{1}$ Unesp, Brasil. Email: beatrizsalgado.co@gmail.com ORCID id: http://orcid.org/0000-0003-2486-5570

${ }^{2}$ No original, para benefício do leitor: "In trying to tell the story of how people attempted to theorize the economic and social life of the cities the name of Walter Benjamin is commonly absent from what we might loosely refer to as the canon of urban studies. This should not be so" (Keith, 2003: 410).

${ }^{3}$ Chamo aqui de "escritos urbanos" textos de Walter Benjamin, de várias naturezas, que versam sobre cidades ou a tomam como contexto primordial de suas reflexões. Como exemplo, podemos citar grande parte dos escritos de Imagens do Pensamento (Benjamin, 2011a: 135-263); o conjunto de aforismos de Rua de Mão Única (Benjamin, 2011a: 7-65); os textos de Infância em Berlim por volta de 1900 (Benjamin, 2011a: 66-134); seus ensaios sobre Paris, como Paris do Segundo Império (Benjamin, 2011b: 9-102); suas narrativas radiofônicas (Benjamin, 2015); e, evidentemente, o Projeto das Passagens (Benjamin, 2018).

4 Analisei alhures (Oliveira, 2017b) linhagens contemporâneas dos estudos urbanos fortemente influenciadas pela obra de Benjamin. Os pesquisadores e etnógrafos urbanos destas linhagens inspiramse, principalmente, na figura do flâneur e no estilo de escrita fragmentário dos escritos de Benjamin sobre a cidade para articularem suas reflexões e investigações sobre o urbano.
} 
É possível que a razão seja seu gênero de escrita singular. Com efeito, Benjamin não procurava fazer teoria no sentido tradicional do termo, uma teoria que violentasse o caráter fragmentário de sua obra (Rouanet, 1987), ou a expressão assistemática de seu pensamento (Wizisla, 2015). Isso não quer dizer, porém, que seu pensamento não possa ser sistematizado de alguma maneira.

O caráter literário ou ensaístico de sua obra pode vir a anuviar a figura de um autor preocupado com a organização e a classificação do pensamento. Seu trabalho mais célebre, o Projeto das Passagens (Benjamin, 2018), é um bom exemplo desta faceta benjaminiana. A publicação que conhecemos, organizada em 1982 por Rolf Tiedemann, conta com mais de 4.000 fragmentos classificados em 36 cadernos temáticos, na coletânea "Notas e Materiais" (Bolle, 2015: 88). Este esforço taxonômico do autor adquire ainda maior empenho em uma planta de construção das Passagens, descoberta em 1981, na Bibliothèque Nationale de Paris. Willi Bolle nota:

Nessa planta, composta ao todo por 86 páginas manuscritas e que representa o estágio mais avançado do Projeto das Passagens, Benjamin organiza a história social da cidade de Paris por ele planejada por meio de 30 categorias construtivas como, por exemplo, "Fisiognomia do inferno", "Antiguidade parisiense", "Mercado Literário", "Novidade" etc. (Bolle, 2015: 88, grifos da pesquisadora).

Sem sombra de dúvida, este trabalho constitui um estágio muito avançado de seu pensamento. Antes de iniciar a redação de sua planta, pode-se dizer que Benjamin realizou uma série de experimentações. Por exemplo, Carlos Eduardo Jordão Machado argumenta que, em Rua de Mão Única (Einbahnstrasse) (Benjamin, 2011a), coleção de aforismos redigida entre 1923-1928, Benjamin dá início a um processo de experimentação da "montagem literária", que encontrará seu ponto culminante no Projeto das Passagens (Machado, 2015).

No mesmo período em que redige Rua de Mão Única, na década de 1920, o autor também se dedica a outros ensaios, publicados no Brasil na coleção de textos de Imagens do pensamento (2011a). Dentre estes ensaios, podemos encontrar aqueles que representam o crepúsculo de sua aguda percepção sobre o ambiente urbano, como o escritos intitulados "Nápoles", "Moscou" e "Berlim".

O objetivo deste artigo é investigar, por meio de uma organização temática baseada numa leitura minuciosa do texto de Benjamin e nas análises de três comentadores, o ensaio "Nápoles", apontado como uma das primeiras tentativas de 
Benjamin de "representar o ambiente urbano e sua população, de dar voz à sua fascinação com a cidade" (Gilloch, 1996: 21).

\section{Benjamin, viajante}

Seria difícil realizar uma análise de qualquer escrito de Benjamin separando sua vida de sua obra. A biografia peculiar, e mesmo trágica deste autor, impacta profundamente sua produção intelectual. Atento a isso, Graemme Gilloch (1996) dá especial ênfase ao contexto no qual o ensaio "Nápoles" foi escrito, o ano de 1924 que, segundo ele, foi um “divisor de águas” na vida intelectual de Benjamin.

Neste período, o autor viajou à Capri, ilha situada no Golfo de Nápoles, para se juntar a um grupo de amigos e trabalhar mais calmamente em seu estudo do drama barroco alemão. Gershom Scholem lembra, em suas correspondências, que esta não era a única razão para a viagem - os problemas matrimoniais e financeiros de Benjamin foram determinantes (Benjamin; Scholem; Adorno, 1994). Capri também lhe trouxe uma grande surpresa: a atriz bolchevique Asja Lacis, que teria, mais tarde, grande influência na vida e obra do autor (Gilloch, 1996: 21-22).

Foi neste contexto, de precariedade financeira, problemas matrimoniais, e um novo relacionamento, ao menos intelectualmente produtivo, que Benjamin realiza excursões em território italiano, e recolhe o material que, mais tarde, dará origem ao ensaio "Nápoles". O autor comenta em correspondência escrita a Scholem, em 16 de setembro de 1924: "Vi Salerno no mesmo dia. E Pompéia pela segunda vez, e Nápoles talvez pela vigésima vez. Reuni muito material sobre Nápoles, observações importantes e dignas de nota que talvez eu possa transformar em algo" (Benjamin, Scholem, Adorno, 1994: 250, tradução da pesquisadora $)^{5}$.

Essas viagens de Benjamin a Nápoles culminarão em um ensaio que leva o nome da cidade, assinado por ele e Asja Lacis, e publicado mais tarde no Frankfurter Zeitung, em 9 de agosto de 1925 (Gilloch, 1996: 22).

\section{"Nápoles", crepúsculo das Passagens}

\footnotetext{
${ }^{5}$ No original, para benefício do leitor: "I saw Salerno on the same day. And Pompeii for the second time, and Naples for perhaps the twentieth time. I have collected a lot of material on Naples, noteworthy and important observations that I may be able to develop into something" (Benjamin, 1994: 250).
} 
Como comentei anteriormente, uma série de escritos e ensaios sobre cidades visitadas e experienciadas por Benjamin constituem espécies de experimentos para seu grande Projeto. Susan Buck-Morss, importante comentadora da obra benjaminiana, dá atenção especial a quatro cidades: Paris, Moscou, Nápoles e Berlim. A autora as organiza em um diagrama (reproduzido abaixo), no qual cada uma representa um ponto cardeal. Juntas, constituiriam as origens espaciais do Projeto das Passagens.

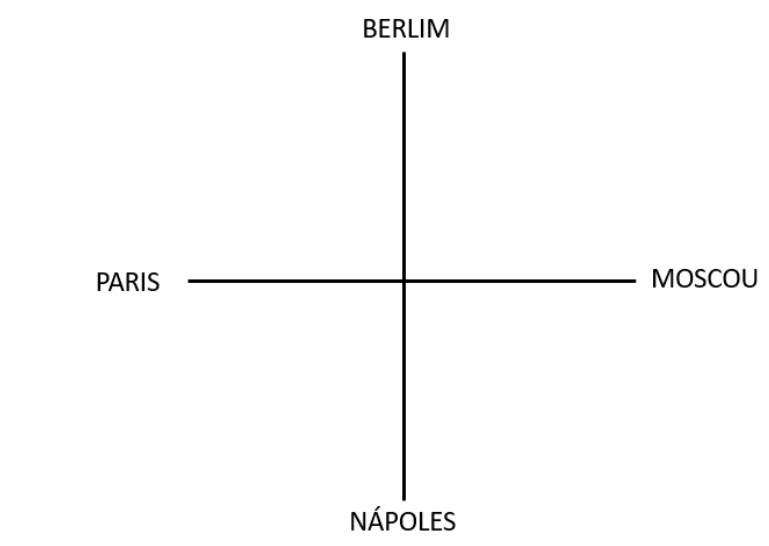

Figura 1 - Reprodução do diagrama de Susan Buck-Morss (2002: 50).

Sobre tal disposição, Buck-Morss argumenta:

A Oeste, situa-se Paris, a origem da sociedade burguesa no sentido políticorevolucionário; a Leste, Moscou, no sentido oposto, marca o fim desta mesma linha. A Sul, Nápoles localiza, nas suas origens mediterrâneas, a infância da civilização ocidental, como mortalha mítica; ao Norte, Berlim representa a infância, em mortalha mítica, do próprio autor (Buck-Morss, 2002: 50, grifos da pesquisadora).

Esta descrição e o tipo de conexão que traça entre tais cidades, certamente não é unânime, sendo criticada, diretamente, por outro comentador de Benjamin, Gilloch (1996), que argumenta que os escritos sobre estas cidades possuem de fato grande importância na obra benjaminiana, porém por razões diversas.

Para Gilloch, os ensaios sobre Nápoles e Moscou possuem natureza mais experimental, enquanto os escritos sobre Berlim e Paris constituem trabalhos mais desenvolvidos: “"Nápoles' contém em si a gênese e a tentativa inicial de articulação de um número de considerações metodológicas e temáticas vitais" ${ }^{\prime 6}$ (Gilloch, 1996: 22), em uma espécie de experimentação literária, e também epistemológica, para a constituição

\footnotetext{
${ }^{6}$ No original, para benefício do leitor: "Naples' contains within it the genesis and tentative initial articulation of a number of vital methodological and thematic considerations" (GILLOCH, 1996: 22).
} 
posterior do Projeto das Passagens. Tanto Gilloch como Buck-Morss dedicam algumas páginas à análise de "Nápoles", que serão aqui constantemente referenciadas.

Sobre a colocação de Gilloch, cabe notar que, por um lado, em "Nápoles", Benjamin realiza a experimentação de um estilo textual, caracterizado pela variedade e mistura temática, e pela fragmentariedade ${ }^{7}$. Gilloch denomina-o "estilo jornalístico", ou "forma literária imediata", "entrelaçada com suas preocupações políticas” (Gilloch, 1996: 23, tradução da pesquisadora).

$\mathrm{Na}$ realidade, podemos caracterizar tal estilo textual como manifestação da própria construção de conhecimento do autor - uma nova forma de escrita, que condiz com a modernidade e que objetiva conectar-se à "construção específica do objeto analisado" (Machado, 2015: 136). De fato, "Nápoles" indica o nascimento de um estilo literário que tem em sua base uma forte preocupação epistemológica, reiterada por vários autores e comentaristas da obra de Benjamin:

Um tema recorrente nos textos de Benjamin sobre a cidade é a tentativa de inventar um modo ou estilo de escrita que, de algum modo, incorpore ou encarne a experiência urbana (...). Trata-se de uma tentativa de capturar o caráter transitório e momentâneo da vida social em um conjunto de imagens (Gilloch, 1996: 23, tradução da pesquisadora) ${ }^{8}$.

Por outro lado, e não menos importante, é possível notar que temas sobre o urbano e a sociedade urbana que vêm à tona neste ensaio, irão ecoar de forma profunda em escritos posteriores do autor, como procurarei notar ao longo do artigo. Em especial, Gilloch nota que emerge com mais força nos ensaios sobre Nápoles e Moscou a concepção de Imagens de Pensamento (Denkbilder) ${ }^{9}$, como “formas de 'instantâneos' literários", nos quais o "efêmero é congelado e preservado" (Gilloch, 1996: 23, tradução da pesquisadora).

\section{Um leitmotiv e suas derivações}

Se Benjamin pôs-se a escavar meticulosamente o solo das cidades modernas, em um intento de alcance extremamente menor e incomparavelmente mais humilde do que

\footnotetext{
${ }^{7}$ Analisei alhures o estilo textual deste e outros escritos benjaminianos sob a influência do Romantismo de Iena (Oliveira, 2017a).

${ }^{8}$ No original, para benefício do leitor: "A recurrent theme of Benjamin's texts on the city is the attempt to devise a mode or style of writing that in some ways incorporates or embodies within the urban experience (...). It is an attempt to capture the fleeting, momentary character of social life in a set of images" (Gilloch, 1996: 23).

${ }^{9}$ Explorar este conceito benjaminiano, já escrutinado por tantos comentadores, está além dos limites deste artigo e, certamente, além das capacidades desta autora. Por isso, apenas faço referência às colocações de Gilloch para aqueles que desejam consultar com mais profundidade a temática.
} 
o do autor, propus-me a escarvar um de seus escritos. Apresento aqui um experimento de inspiração arqueológica, por sua natureza paciente e seu intento classificatório, no solo de "Nápoles".

Antes, a fim de honrar a arqueologia benjaminiana, recomponho os caminhos por mim percorridos. Realizei a leitura do ensaio "Nápoles" pela primeira vez quando da redação de minha dissertação de mestrado, entre 2015 e 2016. Ainda não havia tomado contato com as análises específicas dos comentadores do autor sobre este escrito, por isso, pode-se dizer que minha leitura foi mais "livre" e "criativa". Ela deu origem a uma primeira tabela temática, desenvolvida por meio da definição de temas para determinados trechos do texto. O mesmo procedimento foi realizado com dois outros ensaios, "Moscou" e "Marselha". Ao final desta incursão, notei uma comunhão temática entre os três escritos, que indicaram uma atenção especial do autor a certas facetas do urbano. Visto que a esta análise é apresentada em forma de artigo, e implica em uma extensão limitada, optei por trabalhar apenas com "Nápoles".

Ao longo da leitura das análises de comentadores como Buck-Morss (2002), Gilloch (1996), e Andrew Benjamin (2005), dedicadas especificamente a este ensaio, passei a "recolher" as principais temáticas apontadas por eles, articulando-as com minha antiga tabela e fazendo adaptações e modificações. Este trabalho deu origem a um novo esquema, também elaborado em uma tabela, apresentada abaixo.

Esta tabela esquematiza o ensaio sobre Nápoles em três categorias. A primeira, o tema central, ou "leitmotiv" do ensaio - a ideia de "porosidade". Por determinar ou mesmo perfazer as outras temáticas, situa-se na primeira linha da tabela, encabeçando tudo o que segue. À esquerda, na primeira coluna, estão trechos do ensaio de Benjamin, reproduzidos da publicação brasileira de Imagens do Pensamento (Benjamin, 2001a), e numerados de "1" a "38". A segunda coluna nota a página de cada excerto, de acordo com a edição utilizada. A terceira coluna denota o "subtema" a que se refere a citação e, por fim, a quarta coluna aponta seu tema. Dessa maneira, lendo a tabela da esquerda para a direita, vai-se do mais específico e detalhado - as próprias colocações de Benjamin - ao mais abstrato - os temas determinados por minha leitura e/ou pela leitura dos comentadores.

Evidentemente, meu objetivo não foi reduzir "Nápoles" em frias taxonomias, corrompendo a própria natureza do pensamento de Benjamin, mas sim realizar um 
esforço de sistematização de sua produção, a fim de identificar as temáticas mais caras ao autor, que figuram em seus escritos posteriores e que podem ser de importância teórica para reflexões contemporâneas sobre a cidade .

Tabela Temática - "Nápoles"

\begin{tabular}{|c|c|c|c|c|}
\hline \multicolumn{5}{|c|}{ POROSIDADE } \\
\hline & FRAGMENTO & PÁGINA & SUBTEMA & TEMA \\
\hline 1 & $\begin{array}{c}\text { "Há alguns anos, por causa das transgressões morais, um } \\
\text { padre era conduzido numa carreta pelas ruas de Nápoles. } \\
\text { Lançando imprecações, pessoas os seguiam. O padre se } \\
\text { ergue, faz o sinal da cruz, e todos os que estão atrás da } \\
\text { carreta caem de joelhos. É dessa maneira incondicional que o } \\
\text { catolicismo se empenha por se restabelecer nesta cidade, } \\
\text { qualquer que seja a circunstância. Se um dia desaparecesse } \\
\text { da face da Terra, seu último reduto não seria Roma, mas } \\
\text { Nápoles" }\end{array}$ & 136 & $\begin{array}{l}\text { IMAGEM DE } \\
\text { PENSAMENTO - } \\
\text { ABERTURA }\end{array}$ & $\begin{array}{l}\text { SAGRADO E } \\
\text { PROFANO }\end{array}$ \\
\hline 2 & $\begin{array}{c}\text { "Não pode esse povo viver de acordo com sua imensa } \\
\text { barbárie, crescida do coração da própria cidade grande, em } \\
\text { lugar algum com mais segurança que no seio da Igreja." } \\
\text { "Apenas a Igreja, e não a polícia, pode se equiparar à } \\
\text { autonomia da criminalidade, a Camorra" }\end{array}$ & 136 & $\begin{array}{c}\text { RELIGIÃO E POLÍTICA } \\
\text { RELIGIÃO COMO } \\
\text { POLÍCIA }\end{array}$ & $\begin{array}{l}\text { SAGRADO E } \\
\text { PROFANO }\end{array}$ \\
\hline 3 & $\begin{array}{c}\text { "Mas tampouco o viajante comum se sai melhor. O próprio } \\
\text { guia Baedeker não poderia tranquilizá-lo. Aqui as Igrejas não } \\
\text { se deixam achar" }\end{array}$ & 137 & $\begin{array}{c}\text { MAPA } \\
\text { ARQUITETURA }\end{array}$ & $\begin{array}{c}\text { (DES)ORIENTAÇÃO } \\
\text { NA CIDADE }\end{array}$ \\
\hline
\end{tabular}




\begin{tabular}{|c|c|c|c|c|}
\hline 4 & $\begin{array}{c}\text { "A pobreza e a miséria atuam contagiosamente da mesma } \\
\text { forma como são apresentadas às crianças, e o medo tolo de } \\
\text { ser explorado é apenas a racionalização mesquinha desse } \\
\text { sentimento." } \\
\text { "Um mendigo jaz na rua, apoiado contra o meio fio, e agita, } \\
\text { como quem se despede na estação ferroviária, o chapéu } \\
\text { vazio" }\end{array}$ & 137 & $\begin{array}{c}\text { MISÉRIA E } \\
\text { MENDICÂNCIA } \\
\text { PERFORMANCE }\end{array}$ & ESPETÁCULO \\
\hline 5 & $\begin{array}{l}\text { "No Hospital San Genaro dei Poveri a entrada é um complexo } \\
\text { de edifícios brancos que conduz a dois pátios. De ambos os } \\
\text { lados da passagem ficam os bancos dos doentes graves, que } \\
\text { acompanham os que saem com olhares que não revelam se } \\
\text { agarram às suas roupas para ganharem a liberdade ou para } \\
\text { neles expiarem desejos inimagináveis; atrás delas, os } \\
\text { aleijados exibem suas mutilações, e sua alegria é o espanto } \\
\text { dos que passam distraídos" }\end{array}$ & $137-138$ & $\begin{array}{c}\text { DOENTES E } \\
\text { ALEIJADOS } \\
\text { PERFORMANCE }\end{array}$ & ESPETÁCULO \\
\hline 6 & $\begin{array}{l}\text { "'Pompéia" torna irresistíveis as imitações em gesso das } \\
\text { ruínas do templo, a corrente de massa de lava e o cicerone } \\
\text { piolhento" } \\
\text { "É compreensivel que a Madona milagrosa que lá reina, } \\
\text { ganhe uma igreja novinha em folha e suntuosa" }\end{array}$ & 138 & $\begin{array}{c}\text { RUIÍNAS } \\
\text { TRADIÇÃO COMO } \\
\text { MERCADORIA }\end{array}$ & $\begin{array}{l}\text { ARCAICO E } \\
\text { MODERNO }\end{array}$ \\
\hline 7 & $\begin{array}{c}\text { "Fantásticos relatos de viajantes aquarelam a cidade. Na } \\
\text { verdade, ela é cinzenta: um vermelho ou um ocre cinzento. E } \\
\text { totalmente cinzenta na direção do céu e do mar" } \\
\text { "Pois quem não entende de formas tem pouco a ver aqui. A } \\
\text { cidade é rochosa" }\end{array}$ & 138 & VISÃO & SENTIDOS \\
\hline 8 & $\begin{array}{l}\text { "A arquitetura é porosa como essas rochas. Construção e } \\
\text { ação se entrelaçam uma à outra em pátios, arcadas e } \\
\text { escadas. Em todos os lugares se preservam espaços capazes } \\
\text { de se tornar cenário de novas e inéditas constelações de } \\
\text { eventos. Evita-se cunhar o definitivo" }\end{array}$ & 138 & $\begin{array}{l}\text { ARQUITETURA } \\
\text { MOVIMENTO }\end{array}$ & TEMPO E ESPAÇO \\
\hline 9 & $\begin{array}{c}\text { "Ninguém se orienta pela numeração das casas. São lojas, } \\
\text { fontes e igrejas que dão os pontos de referência. Nem sempre } \\
\text { fáceis. Pois a igreja napolitana, em geral, não se ostenta num } \\
\text { espaço gigantesco com transeptos, coros e cúpulas. Fica } \\
\text { escondida, encaixada" }\end{array}$ & 139 & $\begin{array}{c}\text { CARTOGRAFIA } \\
\text { ARQUITETURA } \\
\text { IGREJA }\end{array}$ & $\begin{array}{c}\text { (DES)ORIENTAÇÃO } \\
\text { NA CIDADE }\end{array}$ \\
\hline 10 & $\begin{array}{l}\text { "(...) impossivel distinguir o volume da igreja do volume das } \\
\text { construções profanas vizinhas. O forasteiro passa sem } \\
\text { percebê-la" } \\
\text { "Um passo o transfere da balbúrdia de pátios sujos para a } \\
\text { integra solidão do ambiente espaçoso e caiado da igreja. Sua } \\
\text { existência privada é a desembocadura barroca de elevada } \\
\text { publicidade (...). Travessas permitem que o olhar resvale, por } \\
\text { sobre degraus sujos, para dento de botequins, onde bebem } \\
\text { três ou quatro homens sentados, isolados e ocultos atrás de } \\
\text { tonéis como se fossem colunas de igrejas" }\end{array}$ & 139 & $\begin{array}{c}\text { ARQUITETURA } \\
\text { INTERIOR E EXTERIOR }\end{array}$ & $\begin{array}{l}\text { SAGRADO E } \\
\text { PROFANO }\end{array}$ \\
\hline 11 & $\begin{array}{c}\text { "Em tais recantos mal se percebe o que ainda está sob } \\
\text { construção e o que já entrou em decadência. Pois nada está } \\
\text { pronto, nada está concluído" }\end{array}$ & 139 & $\begin{array}{c}\text { ESPAÇO } \\
\text { MOVIMENTO }\end{array}$ & $\begin{array}{l}\text { ARCAICO E } \\
\text { MODERNO }\end{array}$ \\
\hline 12 & $\begin{array}{c}\text { "Balcões, átrios, janelas, portões, escadas, telhados, são ao } \\
\text { mesmo tempo palco e camarote. Mesmo a existência mais } \\
\text { miserável é soberana no vago conhecimento de atuar em } \\
\text { conjunto, em toda a perversão, numa cena de rua napolitana, } \\
\text { que nunca se repete" }\end{array}$ & 139 & $\begin{array}{l}\text { IMPROVISÃO E } \\
\text { PERFORMANCE }\end{array}$ & ESPETÁCULO \\
\hline
\end{tabular}




\begin{tabular}{|c|c|c|c|c|}
\hline 13 & $\begin{array}{c}\text { "A decoração nas ruas tem, também materialmente, estreito } \\
\text { parentesco com a do teatro. O papel é o protagonista. } \\
\text { Enxota-moscas vermelhos, azuis, amarelos, altares de papel } \\
\text { acetinado nos muros, rosetas de papel nos pedaços crus de } \\
\text { carne" }\end{array}$ & 140 & VISÃO & SENTIDOS \\
\hline 14 & $\begin{array}{l}\text { "Alguém se ajoelha no asfalto, ao seu lado uma caixinha, e a } \\
\text { rua é a das mais animadas. Com giz colorido desenha na } \\
\text { pedra um Cristo, mais ou menos embaixo, a cabeça da } \\
\text { Madona. Entrementes, um círculo se fechou à sua volta; o } \\
\text { artista se ergue, e, enquanto espera ao lado de sua obra } \\
\text { durante quinze, trinta minutos, da roda caem escassas } \\
\text { moedas (...). Até que ele as recolha, todos se dispersam, e, } \\
\text { em poucos instantes, o desenho está pisoteado" }\end{array}$ & 140 & $\begin{array}{l}\text { PERFORMANCE } \\
\text { COMÉRCIO E } \\
\text { VARIETÉS }\end{array}$ & ESPETÁCULO \\
\hline 15 & $\begin{array}{c}\text { "Entre tais habilidade, comer macarrão com as mãos não é a } \\
\text { menos importante. Com uma remuneração, isso é mostrado a } \\
\text { estrangeiros. Outras coisas se fazem pagar segundo uma } \\
\text { tarifa" }\end{array}$ & 140 & $\begin{array}{l}\text { TRADIÇÃO COMO } \\
\text { MERCADORIA }\end{array}$ & $\begin{array}{l}\text { ARCAICO E } \\
\text { MODERNO }\end{array}$ \\
\hline 16 & $\begin{array}{l}\text { "Música circula ao redor: não melancólica para os pátios } \\
\text { fechados, mas radiante para as ruas. A larga carreta, uma } \\
\text { espécie de xilofone, está carregada de textos em cores das } \\
\text { canções. Aqui eles podem ser comprados" }\end{array}$ & 140 & $\begin{array}{l}\text { AUDIÇÃO } \\
\text { VISÃO }\end{array}$ & SENTIDOS \\
\hline 17 & $\begin{array}{l}\text { "Essa música é resquício do último feriado e prelúdio do } \\
\text { seguinte. O feriado penetra sem resistência qualquer dia de } \\
\text { trabalho. A porosidade é a lei inesgotável dessa vida, a ser } \\
\text { redescoberta. Um grão do domingo se esconde em todo dia } \\
\text { de semana, e quantos dias de semana nesse domingo!" }\end{array}$ & $140-141$ & AUDIÇÃO & TEMPO E ESPAÇO \\
\hline 18 & $\begin{array}{l}\text { "Meninos coloridos pescam em regatos de azul profundo e } \\
\text { levantam olhos na direção de torres supermaquiladas de } \\
\text { vermelho. No alto, por cima das ruas, se estendem varais } \\
\text { onde as roupas se penduram como flâmulas ordenadas" }\end{array}$ & 141 & VISÃO & SENTIDOS \\
\hline 19 & $\begin{array}{c}\text { "Sóis delicados se acendem nas tinas de vidro com bebidas } \\
\text { geladas. Dia e noite reluzem esses pavilhões com os pálidos } \\
\text { sumos aromáticos, com os quais a própria língua aprende o } \\
\text { que significa porosidade" }\end{array}$ & 141 & $\begin{array}{l}\text { VISÃO } \\
\text { OLFATO } \\
\text { PALADAR }\end{array}$ & SENTIDOS \\
\hline 20 & $\begin{array}{c}\text { "Mas se política ou calendário, de algum modo, for propício, } \\
\text { então tudo o que é secreto e dividido colide na festa ruidosa. } \\
\text { E, em geral, ela é coroada com um fogo de artifício sobre o } \\
\text { mar (...). Aqui o fogo tem corpo e alma (...)" }\end{array}$ & 141 & $\begin{array}{c}\text { AUDIÇÃO } \\
\text { VISÃO } \\
\text { PERFORMANCE }\end{array}$ & PÚBLICO E PRIVADO \\
\hline 21 & $\begin{array}{l}\text { "Em primeiro lugar, o estrondo galha de qualquer apoteose } \\
\text { as graças do povo. Em Piedigrotta, na festa principal dos } \\
\text { napolitanos, esse prazer infantil pelos estrondos assume uma } \\
\text { feição selvagem. Na noite de oito de setembro hordas } \\
\text { compostas de até cem homens enfiam por todas as ruas. } \\
\text { Sopram enormes cartuchos (...)." }\end{array}$ & 141 & $\begin{array}{c}\text { AUDIÇÃO } \\
\text { PERFORMANCE }\end{array}$ & ESPETÁCULO \\
\hline 22 & $\begin{array}{c}\text { "Negócios inteiros se baseiam no espetáculo. Os pequenos } \\
\text { jornaleiros esticam na boca exemplares do Roma e do Correi } \\
\text { di Napoli, como hastes de borracha. Seus berros são } \\
\text { manufatura urbana" }\end{array}$ & $141-142$ & $\begin{array}{l}\text { COMÉRCIO E } \\
\text { VARIETÉS } \\
\text { PERFORMANCE } \\
\text { AUDIÇÃO }\end{array}$ & ESPETÁCULO \\
\hline 23 & $\begin{array}{l}\text { "A loteria, irresistível e ardente como em nenhuma outra } \\
\text { parte da Itália, permanece a típica atividade de sustento. } \\
\text { Todo sábado, às quatro, pessoas se aglomeram no pátio da } \\
\text { casa onde se extraem os números (...). A embriaguez mais } \\
\text { ponderada e mais liberal do jogo de azar, do qual toda a } \\
\text { família participa, substitui à alcoólica" }\end{array}$ & 142 & PERFORMANCE & ESPETÁCULO \\
\hline
\end{tabular}




\begin{tabular}{|c|c|c|c|c|}
\hline 24 & $\begin{array}{l}\text { "Um sujeito se acha numa caleça desatrelada em certa } \\
\text { esquina. Pessoas se apinham ao redor. A boleia está aberta, e } \\
\text { o vendedor dela retira alguma coisa que não para de } \\
\text { apregoar. Antes que possa ser vista, desaparece num } \\
\text { papelote colorido de rosa ou de verde. Assim ele a ergue e } \\
\text { num instante é vendida por poucos soldi." }\end{array}$ & 142 & $\begin{array}{l}\text { COMÉRCIO E } \\
\text { VARIETÉS } \\
\text { PERFORMANCE }\end{array}$ & ESPETÁCULO \\
\hline 25 & $\begin{array}{c}\text { "Sobre o divertido prazer de negociar do napolitano existem } \\
\text { histórias graciosas. Numa Piazza movimentada escapole o } \\
\text { leque da mão de uma senhora gorda. Desamparada, olha ao } \\
\text { redor; não está em forma para recolhê-lo por si própria. Um } \\
\text { cavaleiro aparece e se dispõe a prestar esse serviço por } \\
\text { cinquenta liras. Negociam, e a senhora recupera seu leque } \\
\text { por dez" }\end{array}$ & 143 & $\begin{array}{l}\text { COMÉRCIO E } \\
\text { VARIETÉS } \\
\text { PERFORMANCE }\end{array}$ & ESPETÁCULO \\
\hline 26 & $\begin{array}{l}\text { "A vida doméstica é repartida, porosa e entremeada. O que } \\
\text { distingue Nápoles de todas as grandes cidades é a afinidade } \\
\text { com o kral dos hotentotes: cada atitude e desempenho } \\
\text { privado é inundado por correntes da vida comunitária" }\end{array}$ & 143 & $\begin{array}{l}\text { VIDA COLETIVA E } \\
\text { VIDA PRIVADA }\end{array}$ & PÚBLICO E PRIVADO \\
\hline 27 & $\begin{array}{c}\text { "Por isso a casa é muito menos o asilo, no qual pessoas } \\
\text { ingressam, do que o reservatório, do qual efluem. Não } \\
\text { apenas de portas irrompe a vida. Não apenas para os átrios, } \\
\text { onde, sentadas em cadeiras, as pessoas executam seus } \\
\text { afazeres (pois tem a faculdade de transformar o corpo em } \\
\text { mesa)" }\end{array}$ & 143 & INTERIOR E EXTERIOR & PÚBLICO E PRIVADO \\
\hline 28 & $\begin{array}{l}\text { "Do mesmo modo como o quarto retoma à rua com cadeiras, } \\
\text { fogão e altar, a rua peregrina quarto adentro, só que com } \\
\text { muito mais rumor. Mesmo o mais pobre dos quartos está tão } \\
\text { repleto de velas, santos de argila, tufos de fotografia na } \\
\text { parede e beliches de ferro, quanto o está a rua de carretas, } \\
\text { gente e luzes (...). Comer e dormir não tem hora, muitas vezes } \\
\text { nem sequer lugar" }\end{array}$ & 144 & INTERIOR E EXTERIOR & PÚBLICO E PRIVADO \\
\hline 29 & $\begin{array}{c}\text { "Os mesmos pratos têm gosto diferente de acordo com o } \\
\text { cozinheiro: nada é processado ao acaso, mas de acordo com } \\
\text { receitas experimentadas" }\end{array}$ & 144 & PALADAR & SENTIDOS \\
\hline 30 & $\begin{array}{l}\text { "Como na vitrine da menor trattoria peixes e carnes se } \\
\text { amontoam à frente do freguês que as avalia, aqui há uma } \\
\text { nuança que ultrapassa as exigências do conhecedor. Para } \\
\text { isso, no mercado de peixe, esse povo de marinheiros realizou } \\
\text { o magnífico refúgio neerlandês. Estrelas do mar, caranguejos, } \\
\text { polvos da água do golfo, onde formigam rebentos } \\
\text { monstruosos, cobrem as bancadas e são frequentemente } \\
\text { engolidos crus com gotas de sumo de limão" }\end{array}$ & 144 & $\begin{array}{l}\text { COMÉRCIO E } \\
\text { VARIETÉS } \\
\text { PERFORMANCE }\end{array}$ & ESPETÁCULO \\
\hline 31 & $\begin{array}{c}\text { "Como seria possível dormir em tais aposentos? Sem dúvida } \\
\text { neles existem tantas camas quantas o espaço permita. Mas, } \\
\text { mesmo que sejam seis ou sete, o que há de moradores é } \\
\text { frequentemente mais do dobro" }\end{array}$ & 144 & INTERIOR E EXTERIOR & PÚBLICO E PRIVADO \\
\hline 32 & $\begin{array}{l}\text { "Aqui também há uma interpenetração do dia e da noite, do } \\
\text { ruído e do silêncio, da luz de fora e da escuridão de dentro, da } \\
\text { rua e do lar" }\end{array}$ & 144 & INTERIOR E EXTERIOR & TEMPO E ESPAÇO \\
\hline
\end{tabular}




\begin{tabular}{|c|c|c|c|c|}
\hline 33 & $\begin{array}{l}\text { "Isso [a porosidade] prossegue até nos brinquedos. Diluída e } \\
\text { com pálidas cores do Kindle de Munique se acha a Madona } \\
\text { nas paredes das casas. O menino que ela estende à sua frente } \\
\text { como um cetro, se encontra desse mesmo jeito, rígido, } \\
\text { enfaixado, sem braço e sem perna, como um boneco de } \\
\text { madeira nas lojas mais pobres de Santa Lucia. Com essa peça } \\
\text { os pirralhos podem bater onde queiram." }\end{array}$ & $144-145$ & BRINQUEDOS & $\begin{array}{l}\text { EXPERIÊNCIA DA } \\
\text { CRIANÇA }\end{array}$ \\
\hline 34 & $\begin{array}{c}\text { "(..) e, assim, ainda hoje, se mantém o Salvador Bizantino. } \\
\text { Madeira bruta na parte posterior; só a parte frontal pintada. } \\
\text { Vestimenta azul, pontinhos brancos, bainha vermelha e } \\
\text { bochechas vermelhas" }\end{array}$ & 145 & BRINQUEDOS & $\begin{array}{l}\text { SAGRADO E } \\
\text { PROFANO }\end{array}$ \\
\hline 35 & $\begin{array}{c}\text { "Nos quarteirões super povoados, mesmo as crianças travam } \\
\text { rapidamente conhecimento como sexo. Mas, se em algum } \\
\text { lugar seu aumento se torna devastador (...) não vão carecer } \\
\text { de um parente mais próximo ou mais afastado. Uma vizinha } \\
\text { aceita à sua mesa uma criança por prazo curto ou longo, e } \\
\text { desse modo as famílias se interpenetram em relações, que } \\
\text { podiam se equiparar à adoção" }\end{array}$ & 145 & PERFORMANCE & $\begin{array}{l}\text { EXPERIÊNCIA DA } \\
\text { CRIANÇA }\end{array}$ \\
\hline 36 & $\begin{array}{l}\text { "Os cafés são verdadeiros laboratórios desse grande processo } \\
\text { de interpenetração. Neles, a vida não tem tempo de se } \\
\text { estabelecer para se estagnar. São espaços abertos e } \\
\text { insípidos, do gênero botequim de políticos (...). Cafés } \\
\text { napolitanos são exíguos. É praticamente impossível uma } \\
\text { permanência mais longa. Uma xícara fervente de caffè } \\
\text { espresso (...) despacha o freguês com uma saudação" }\end{array}$ & 145 & $\begin{array}{c}\text { CAFÉS } \\
\text { MOVIMENTO }\end{array}$ & TEMPO E ESPAÇO \\
\hline 37 & $\begin{array}{c}\text { "A pantomima* é aqui mais usada do que em qualquer outra } \\
\text { parte da Itália. Para o forasteiro, a conversa é insondável. } \\
\text { Ouvidos, nariz, olhos, peito e ombros são postos de sinais } \\
\text { ocupados pelos dedos" }\end{array}$ & 145 & $\begin{array}{l}\text { PERFORMANCE } \\
\text { COMUNICAÇÃO }\end{array}$ & ESPETÁCULO \\
\hline 38 & $\begin{array}{l}\text { "Sim, aqui ele [o estrangeiro] seria traído e vendido, mas o } \\
\text { napolitano bonachão o despede. Manda-o alguns } \\
\text { quilômetros mais à frente, para Mori. - Vedere Napoli e poi } \\
\text { Mori -, diz, repetindo, esse velho gracejo. - Ver Nápoles e } \\
\text { depois morrer, diz o alemão, corroborando" }\end{array}$ & 145 & PEFORMANCE & $\begin{array}{c}\text { (DES)ORIENTAÇÃO } \\
\text { NA CIDADE }\end{array}$ \\
\hline
\end{tabular}

A seguir, o leitmotiv do ensaio de Benjamin e seus temas são analisados. Procurei notar igualmente suas conexões com escritos posteriores do autor e, por vezes, sua presença em estudos as antropologia e sociologia urbanas.

\section{Porosidade}

Aqui, denomino "porosidade" como um leitmotiv do ensaio. Como em uma obra musical, a porosidade é um tema constantemente citado no texto, e que funciona como espécie de amálgama, ligando todas as temáticas trabalhadas, por mais diversas que sejam suas naturezas.

Segundo Gilloch, a porosidade é o "conceito-chave" de representação da cidade em "Nápoles". Buck-Morss lembra que a ideia, na verdade, foi de Lacis, que assina também o ensaio. Segundo a autora, o conceito diz respeito, principalmente, às 
fronteiras modernas do capitalismo, que "ainda não tinham sido estabelecidas", como se Nápoles fosse uma "oca casca em vias de desintegração da ordem pré-capitalista" (Buck-Morss, 2002: 51). Gilloch, por outro lado, acredita que as proposições de BuckMorss são um tanto grandiosas, e que Benjamin tinha intenções mais modestas:

Se em "Nápoles" há, como afirma Buck-Morss, uma preocupação com a representação da "infância da civilização ocidental, como mortalha mítica", é bastante intrigante que Benjamin escreva sobre o cotidiano da vida napolitana e não, por exemplo, sobre as ruínas próximas de Pompéia. Na minha opinião, o ensaio de Benjamin é muito mais modesto em suas intenções. Trata de formas de vida contemporâneas, e não clássicas (Gilloch, 1996: 24, tradução da pesquisadora) ${ }^{10}$.

Apesar de Buck-Morss não ignorar a ênfase dada por Benjamin ao cotidiano napolitano, e apontar que o ensaio apresenta de fato imagens "reunidas [como que] por alguém que caminha pelas ruas de uma cidade" (2002: 52), importância maior é dada em sua análise ao caráter político-teórico do texto. Sua leitura então contrasta com aquelas de Gilloch e Andrew Benjamin que, apesar de não ignorarem as colocações políticas e teóricas do autor, dão maior proeminência à análise temática e estética de Benjamin.

Para Gilloch, a porosidade, como conceito-chave do texto, incide na organização social, espacial e temporal de Nápoles, e aponta para o leitor "o significado do que está escondido" no cotidiano da cidade italiana (Gilloch, 1996: 25). Porosidade refere-se, nesse sentido, a uma "ausência de fronteiras claras entre fenômenos, uma impregnação de uma coisa por outra, uma fusão, por exemplo, do velho e do novo, do público e do privado, do sagrado e do profano" (Gilloch, 1996: 25, tradução da pesquisadora) ${ }^{11}$. Como procurarei demonstrar nas páginas que seguem, cada tema trabalhado em "Nápoles" por Benjamin está sob o julgo da porosidade - nesta cidade, "Evita-se cunhar o definitivo. Nenhuma situação aparece como é, destinada para todo o sempre; nenhuma forma declara o seu 'desta maneira e não de outra'” (Benjamin 2011a: 138-139). Assim, a porosidade encontra-se tanto nas rochas que despontam na paisagem napolitana, como na performance teatral do vendedor ambulante.

\footnotetext{
${ }^{10}$ No original, para benefício do leitor: "If "Naples" is, as Buck-Morss states, concerned with the depiction of the "mith-enshrouded childhood of Western civilization", it is rather puzzling that Benjamin should write about everyday Neapolitan life and not, for example, about the nearby ruins of Pompeii. In my view, Benjamin's essay is far more modest in its intentions. It is about contemporary rather than classical forms of life (Gilloch, 1996: 24).

${ }^{11}$ No original, para benefício do leitor: "Porosity refers to a lack of clear boundaries between phenomena, a permeation of one thing by another, a merger of, for example, old and new, public and private, sacred and profane" (Gilloch, 1996: 25).
} 
Já na leitura de Andrew Benjamin, a ideia de porosidade diz respeito a uma espécie de perfazimento espaço-temporal: ambas estas dimensões "trabalham juntas para definir tanto a condição urbana como o lugar do corpo nela" (Andrew Benjamin, 2005: 35 , tradução da pesquisadora). ${ }^{12}$ Observo mais adiante a leitura que faz o comentador sobre as afirmações de Benjamin em relação ao café napolitano, indicando uma ligação entre espaço-tempo e movimento.

Isso posto, as breves análises que seguem realçam como todas as temáticas no ensaio de Benjamin são vistas sob o prisma da porosidade.

\section{Sagrado e profano}

A abertura do texto de Benjamin já nos remete ao primeiro movimento marcado por nosso leitmotiv - a fusão entre o "sagrado" e "profano". Benjamin inicia:

Há alguns anos, por causa das transgressões morais, um padre era conduzido numa carreta pelas ruas de Nápoles. Lançando imprecações, pessoas os seguiam. O padre se ergue, faz o sinal da cruz, e todos os que estão atrás da carreta caem de joelhos. É dessa maneira incondicional que o catolicismo se empenha por se restabelecer nesta cidade, qualquer que seja a circunstância. Se um dia desaparecesse da face da Terra, seu último reduto não seria Roma, mas Nápoles (Benjamin, 2011a: 136).

O caráter anedótico e trivial desta abertura na verdade possui significância temática e metodológica. Gilloch argumenta que ela reflete um número de temas substantivos do ensaio: "a continua inversão do sagrado e do profano, o poder do Catolicismo, e a forma pública e carnavalesca da vida napolitana" (Gilloch, 1996: 30, tradução da pesquisadora) ${ }^{13}$. Já Andrew Benjamin analisa esta narrativa com maior abstração. Para ele, a anedota não apenas diz respeito à interpenetração entre sagrado e profano, mas justamente introduz ao ensaio a ideia de porosidade, pois que a narrativa é acabada em si e, ao mesmo tempo, possui potencial de criação - abertura e acabamento se interpenetram:

A abertura do ensaio carrega a qualidade de uma narrativa. O texto começa com a evocação de um evento cuja completude marca seu ponto de entrada - a conclusão do evento é tanto recinto da narrativa como criação. Completude e liminaridade se juntam no início do texto (Andrew Benjamin, 2005: 35, tradução da pesquisadora). ${ }^{14}$

\footnotetext{
${ }^{12}$ No original, para benefício do leitor: "Porosity, if only as a beginning, provides a way of making space and time work together to define both the urban condition and the body's place within it" (Andrew Benjamin, 2005: 35).

${ }^{13}$ No original, para benefício do leitor: "First, it reflects a number of substantive themes in his essay: the continual inversion of sacred and profane, the power of Catholicism, and the public and carnivalistic form of Neapolitan life" (Gilloch, 1996: 30).

${ }^{14}$ No original, para benefício do leitor: "The text's opening words carry the quality of a story telling. The text begins with the evocation of an event whose completion marks the point of entry into the text.
} 
Após esta abertura, Benjamin continua a trabalhar com a interpenetração entre o "sagrado e o profano" por meio de outros subtemas. Por exemplo, como mostra o item 2 da tabela, o autor funde a barbárie social e a máfia napolitana (a Camorra) à Igreja, por sua atitude tolerante "em relação aos vícios e delitos" (Gilloch, 1996: 29). Já no item 34, o tema aparece em sua narrativa sobre os brinquedos napolitanos - o "Salvador bizantino" é transformado em objeto lúdico e rústico; com ele, "os pirralhos podem bater onde queiram" (Benjamin, 2011a: 145).

A porosidade entre estas duas dimensões também dará abertura a outro tema, trabalhado a seguir: a "(des)orientação na cidade". O forasteiro benjaminiano que chega à Nápoles tem grande dificuldade ao se locomover. Igrejas são pontos de referência, mas "nem sempre fáceis", pois por vezes é "impossível distinguir o volume da igreja do volume das construções profanas vizinhas". Assim, distraído, apenas um passo transfere o forasteiro "da balbúrdia de pátios sujos para a íntegra solidão do ambiente espaçoso e caiado da igreja" - não há claras fronteiras que demarquem os espaços profanos e os ambientes sagrados. Da mesma maneira, os botequins observados ao longo do caminho pelo viajante lembram as próprias igrejas: "Travessas permitem que o olhar resvale, por sobre degraus sujos, para dento de botequins, onde bebem três ou quatro homens sentados, isolados e ocultos atrás de tonéis como se fossem colunas de igrejas" (Benjamin, 2011a: 139).

\section{(Des)orientação na cidade}

Seguindo o texto cronologicamente, vê-se que a ideia da porosidade é diretamente ligada a temáticas que se tornarão centrais nos escritos urbanos de Benjamin que seguem estas primeiras experiências. Uma delas, quiçá a principal, trata da ideia de deambular pela cidade e se deixar levar pelos seus fluxos.

Ao caminhar por Nápoles, o viajante benjaminiano, mesmo com o "Guia Baedeker" na mão, não se norteia com facilidade, pois “[n]inguém se orienta pela numeração das casas” (Benjamin, 2011a: 139). Já observamos como, com um simples passo, é possível sair dos movimentados pátios napolitanos e adentrar o tranquilo ambiente de uma igreja - perder-se não é difícil.

Completion is both the enclosure into the narrative at the same time is a creation. Completion and threshold conjoin at the text's beginning" (Andrew Benjamin, 2005: 35). 
Pode-se dizer que a concepção desta experiência, tão central na obra de Benjamin, possui dupla influência. Por um lado, da poesia baudelairiana ${ }^{15}$, cuja principal referência é o flâneur - personagem ou "tipo" urbano do século XIX, cuja atividade consistia justamente no deslocamento ocioso e sensível pela cidade. Por outro lado, Benjamin é definitivamente influenciado pelo surrealismo. Nesse sentido, pode-se destacar obras como Nadja, de André Breton, ou O Camponês de Paris, de Louis Aragon, que revelam a cidade como estrutura labiríntica e locus privilegiado da prática da "arte de se perder". Em "Nápoles", a experiência de caminhar pela cidade será, evidentemente, marcada pela ideia de porosidade:

Porosidade é particularmente propícia ao se perder (...). A navegação no labirinto não é uma questão de intelecto ou cálculo, mas depende do acaso e do uso dos sentidos. Só se pode localizar-se pela visão, som e cheiro na imediatidade do ambiente, não pelo estudo cuidadoso de um mapa (Gilloch, 1996: 25-26, tradução e grifos da pesquisadora). ${ }^{16}$

A ideia de se perder na cidade sem perder os sentidos aparecerá mais tarde tanto nos conhecidos trabalhos de Benjamin sobre Paris, como nos escritos sobre sua cidade natal, Infância em Berlim por volta de 1900, dos quais vale ressaltar um excerto, que elucida perfeitamente as colocações de Gilloch sobre "Nápoles". Em Tiergaten, Benjamin afirma:

Saber orientar-se numa cidade não significa muito. No entanto, perder-se numa cidade, como alguém se perde numa floresta, requer instrução. Nesse caso, o nome das ruas deve soar para aquele que se perde como o estalar do graveto seco ao ser pisado, e as vielas do centro da cidade devem refletir as horas do dia tão nitidamente quanto um desfiladeiro (Benjamin, 2011a: 68).

Da (des)orientação sensível na labiríntica Nápoles, deriva outro importante tema que ganhará, igualmente, atenção do autor, especialmente no texto Paris do Segundo Império - a fisiognomonia. Gilloch afirma:

Passear pelas ruas da cidade, decifrar seus espaços e estruturas à medida que se caminha, é a alegria do flâneur e do fisiognomonista. Os conceitos do complexo urbano como um labirinto e do desejo de nele se perder são os motivos mais importantes nos escritos de Benjamin sobre a cidade, e encontram sua articulação

\footnotetext{
${ }^{15}$ Desde sua juventude, Benjamin mostrou-se grande apreciador do trabalho de Baudelaire. Em 1914, o autor começa a trabalhar em traduções de sua poesia para o alemão, o que culminaria, em 1923, na publicação de sua tradução completa de Tableaux Parisiens. Assim, quando de sua viagem à Capri, já tinha amplo contato com a obra do poeta.

16 No original, para benefício do leitor: "Porosity is particularly conducive to losing oneself (...). Navigation in the labyrinth is not a matter of the intellect and calculation, but instead is dependent upon chance and the use of one's senses. One can locate oneself only through the sight, sound and smell of one's immediate surroundings, not through the careful study of a map" (Gilloch, 1996: 25-26).
} 
inicial aqui, na paisagem urbana porosa de Nápoles (Gilloch, 1996: 26, tradução e grifos da pesquisadora). ${ }^{17}$

Dito de maneira um tanto superficial, a fisiognomonia refere-se às "maneiras de dizer e formas de ver o corpo humano: semiologias da exterioridade, da aparência, do invólucro corporais" (Courtine, 2013: 48). Trata-se de um estudo da superfície do corpo, em especial dos traços da face, que tem como intuito revelar o que não é visível exteriormente - a personalidade de um indivíduo.

N'A Paris do Segundo Império (Benjamin, 2011b), Benjamin articula a fisiognomonia do século XVIII com a "literatura panorâmica" do século XIX - de Balzac a Daumier e suas caricaturas, estes artistas realizavam a "colossal passagem em revista da vida burguesa que se estabeleceu França”. Benjamin coloca:

Depois de se terem dedicado aos tipos humanos, chega a vez de se consagrarem à cidade. Apareceram Paris à Noite, Paris à Mesa, Paris na Água, Paris a Cavalo, Paris Pitoresca, Paris Casada. Quando também esse filão se esgotou, os fisiologistas se arriscaram a uma fisiologia dos povos. Tampouco foi esquecida a fisiologia dos animais (...) (Benjamin, 2011b: 34).

Para o autor, o flâneur, ou o "Homem da Multidão" de Edgar Alan Poe, dominam igualmente a arte da fisiognomonia da cidade - decifram tanto os traços dos tipos urbanos como da própria urbe: "A calma dessas descrições combina com o jeito do flâneur, a fazer botânica no asfalto" (Benjamin, 2011b: 34). Da mesma forma, podemos enquadrar Benjamin no papel de fisiognomonista da cidade moderna (Bolle, 1994), cuja trajetória tem como um de seus pontos de partida a cidade italiana.

\section{Sentidos}

Se "Nápoles" e sua porosidade introduzem a temática da (des)orientação na cidade e, com ela, as figuras do flâneur e do fisiognomonista, todos estes elementos, por sua vez, chamam especial atenção que Benjamin dá aos sentidos na exploração urbana. A sensibilidade estética do autor não se resume, certamente, à visão. Sons, odores, gostos e tato também dão o tom às suas observações.

Como é possível notar na tabela temática, experiências sensórias se fazem vastamente presentes em Nápoles. Benjamin observa desde as cores vibrantes dos

\footnotetext{
${ }^{17}$ No original, para benefício do leitor: "To wander the streets of the city, deciphering its spaces and structures as one walks, is the joy of the flaneur and the physiognomist. The concept of the urban complex as a maze and the desire to lose oneself within it are the most important motifs in Benjamin's writings on the city, and they find their initial articulation here, in the porous urban landscape of Naples" (Gilloch, 1996: 26).
} 
enxota-moscas "vermelhos, azuis, amarelos, altares de papel acetinado nos muros, rosetas de papel nos pedaços crus de carne" (Benjamin, 2011a: 140), até os estrondosos sons de Piedegrotta, a festa principal dos napolitanos.

Assim como acontece no ensaio sobre Moscou, quando Benjamin saboreia a tradicional borscht e experiencia um momento sinestésico, no qual visão, olfato, paladar e tato atuam juntos, em "Nápoles" também nos oferece experiências que agregam vários sentidos concomitantemente:

Sóis delicados se acendem nas tinas de vidro com bebidas geladas. Dia e noite reluzem esses pavilhões com os pálidos sumos aromáticos, com os quais a própria língua aprende o que significa porosidade (Benjamin, 2011a: 141).

A sensibilidade às várias dimensões urbanas tem ligação direta, como já introduzi, à ideia de perder-se na cidade sem perder os sentidos. Os "olhos de águia" do flâneur, a aguda percepção do fisiognomonista urbano, captam mesmo o que há de mais efêmero e sutil na urbe.

Vale fazer referência, mais uma vez, ao conto de Edgar Alan Poe, "O Homem da Multidão”. Em sua abertura, Poe descreve um cenário no qual um homem convalescente observa, das vidraças de um café, o espetáculo da multidão que se forma numa das ruas de Londres. A convalescência é relevante na medida em que traz ao personagem grande sensibilidade: "O simples ato de respirar já era uma alegria (...). Sentia um interesse tranquilo, mas curioso, por tudo" (Poe, 2010: 91).

É com todos os sentidos atentos, que o personagem de Poe realizará uma perfeita categorização dos tipos urbanos que emergem da multidão londrina (Oliveira, 2017a: 73) - aqueles que "tinham um ar atarefado e confiante" e outros que eram "incansáveis em seus movimentos; ou ainda aqueles que "tinham sobrancelhas franzidas" e outros que "tinham os rostos afogueados e falavam e gesticulavam sozinhos" (Poe, 2010).

Nesse ponto, os escritos urbanos de Benjamin revelam sua contemporaneidade. A investigação urbana por meio do trabalho com os aspectos sensíveis que vivencia um pesquisador da cidade vem ganhando especial atenção dos estudos da antropologia e sociologia urbanas. Como comenta Carlos Fortuna, “(...) pode-se dizer que se iniciou um novo surto de investigações sobre os novos modos de representação das cidades, de orientação pluridisciplinar" (2013: 103). É possível observar que uma variedade de 
autores estrangeiros dá ênfase à ação dos sentidos na investigação urbana ${ }^{18}$, como o próprio Fortuna, que trabalha com as noções de "paisagens olfativas" e "paisagens sonoras" no âmbito da sociologia urbana. No Brasil, ressalte-se a conhecida proposta de Eckert e Rocha da Etnografia de Rua, que afirma especial "preocupação com a pesquisa antropológica a partir do paradigma estético na interpretação das figurações da vida social na cidade" (2003: 3).

\section{O arcaico e o moderno}

Outra temática importante articulada por Benjamin em "Nápoles" é o perfazimento entre o arcaico e o moderno (como é possível observar nos itens 6, 11 e 15 da tabela). Esta interpenetração é notada tanto na arquitetura napolitana (estrutura física da cidade), quanto na transformação da tradição em mercadoria - tema hoje tão em voga nos estudos urbanos e de turismo - por exemplo nos trabalhos de sociologia e antropologia urbana de Silvano (2009) e Fortuna (2013) -, e agudamente previsto pelo autor, que comenta sobre a tradicional habilidade napolitana de comer macarrão com as mãos: "Com uma remuneração, isso é mostrado a estrangeiros. Outras coisas se fazem pagar segundo uma tarifa" (Benjamin, 2011a: 140).

A esse respeito, Buck-Morss nota que a "vida tradicional" napolitana não é interrompida, mas continuada como "espetáculo para turistas" (Buck-Morss, 2002: 52) - tradição e modernidade se imiscuem em sua forma mercantilizada. Ao longo do texto, Benjamin reitera este aspecto da cidade italiana. Por exemplo, como mostro no item 6 da tabela, o autor comenta a forma pela qual pedaços das ruínas de "Pompéia" e os espólios da erupção de Vesúvio são mostrados aos turistas pelo "cicerone piolhento":

\footnotetext{
"Pompéia" torna irresistiveis as imitações em gesso das ruínas do templo, a corrente de massa de lava e o cicerone piolhento. Esse fetiche é tanto mais milagroso porque o viu, alguma vez, a menor parte daqueles que alimenta. $E$ compreensível que a Madona milagrosa que lá reina, ganhe uma igreja novinha em folha e suntuosa. É nessa construção, e não na [Casa dei Vetti] ${ }^{19}$, que Pompéia vive para $\mathrm{s}$ napolitanos. E onde a malandragem e a miséria, afinal, sempre retomam a casa" (Benjamin, 2011a: 138, grifos da pesquisadora).
}

\footnotetext{
${ }^{18}$ Em minha dissertação de mestrado (Oliveira, 2017a), ofereço um levantamento bibliográfico mais conciso sobre autores contemporâneos que trabalham com o aspecto sensível nos estudos urbanos, como por exemplo Gottschalk (1995); Bochard (1998); Jenks e Neves (2000); Soukup (2013); Pink (2008); Bassett (2007); Myers (2011), dentre tantos outros.

${ }^{19}$ A tradução brasileira menciona "Casa dos Vétios". Dei preferência ao termo original, em italiano, por não encontrar uma tradução corrente para o termo.
} 
Gilloch também leva sua atenção a este aspecto da cidade italiana, e aponta como as ruínas possuem significados bastante diferentes para os turistas e para os nativos:

Enquanto para os primeiros [turistas] elas são um objeto de contemplação, para os segundos [nativos] elas possuem uma utilidade prática e imediata como fonte de renda. Para os napolitanos, as ruínas não são "mortas", mas sim são meios de ganhar a vida (Gilloch, 1996: 32, tradução da pesquisadora). ${ }^{20}$

Em uma análise sobre os escritos urbanos de Benjamin, Michael Keith procura demonstrar como esta é uma das temáticas centrais da obra do autor, e aparecerá, de maneira ora evidente ora sutil, por toda sua produção sobre a cidade:

Se Marx e Engels mostraram as condições materiais de produção por meio das quais o próprio tecido social torna-se mercantilizado, então Benjamin expõe a maneira pela qual este processo de mercantilização não apenas permeia todas as formas culturais, mas também realiza a mediação entre as práticas de representação cultural. Ele é efetivamente um cartógrafo pioneiro dos nexos entre cultura e capital (Keith, 2003: 421, tradução da pesquisadora $)^{21}$.

\section{Do público e privado ao intérieur burguês}

Outra temática marcante de "Nápoles" introduzida pelo leitmotiv da porosidade é a relação entre os domínios público e privado. A polaridade entre o interior da casa e a rua, ou entre a vida particular e pública, é desfeita por Benjamin nesta leitura urbana:

Do mesmo modo como o quarto retoma à rua com cadeiras, fogão e altar, a rua peregrina quarto adentro, só que com muito mais rumor. Mesmo o mais pobre dos quartos está tão repleto de velas, santos de argila, tufos de fotografia na parede e beliches de ferro, quanto o está a rua de carretas, gente e luzes (...). Comer e dormir não tem hora, muitas vezes nem sequer lugar" (Benjamin, 2011a: 144).

Andrew Benjamin observa corretamente que esta espécie de "desfazimento" (undoing) de fronteiras em "Nápoles" não é o mesmo que destruição, mas é característica própria da porosidade, e intrinsecamente ligado ao movimento e à interpenetração. A porosidade, nesse sentido, pode ser vista menos como um adjetivo e mais como verbo, por ter uma dimensão ativa, que "vem a definir o que é usualmente tido como estático ou completo" (Andrew Benjamin, 2005: 37-38, tradução da

\footnotetext{
${ }^{20}$ No original, para benefício do leitor: "Whereas for the former they are an object of contemplation, for the latter they have an immediate, practical utility as a source of income. For the Neapolitan, the ruins are not "dead", but rather a means of earning a living" (Gilloch, 1996: 32).

${ }^{21}$ No original, para benefício do leitor: "'If Marx and Engels display the material conditions of production through which the very fabric of social life becomes commodified then Benjamin exposes the manner in which this process of commodification not only permeates all cultural forms but is also mediates though the practices of cultural representation. He is effectively a pioneering cartographer of the nexus between culture and capital" (Keith, 2003: 421).
} 
pesquisadora $)^{22}$. Nessa acepção, o privado napolitano não existe em polaridade com o público, mas existe apenas em justaposição a ele.

Esta mesma temática se fará presente em outros escritos de Benjamin. É possível comparar a porosidade napolitana entre público e privado, com o interior burguês parisiense ou berlinense, que despontará em Infância em Berlim e também n'A Paris do Segundo Império e nas Passagens. Vale lembrar um dos fragmentos de seção "O Intérieur, o Rastro" do Projeto:

A dificuldade de refletir sobre o habitar: por um lado deve-se reconhecer nele o elemento mais antigo - talvez eterno -, o reflexo da estada do homem no ventre materno; por outro (...) é preciso compreender o habitar, em sua forma mais extrema, como um modo de existência do século XIX. A forma primeva de todo o habitar é a existência não numa casa, mas num casulo. Esse traz a impressão de seu morador. (...) O século XIX (...) [e]ntendida a moradia como o estojo do homem (...) (Benjamin, 2018: 374).

Se o interior burguês do século XIX era marcado por sua variedade de estojos, “capas protetoras, passadeiras, cobertas e guarda-pós”, que encapsulavam o indivíduo em sua própria habitação, Benjamin observa, quem sabe por meio de Nápoles, que o interior do século XX "com sua porosidade e transparência, seu gosto pela vida em plena luz e ao ar livre, pôs um fim à maneira antiga de habitar" (Benjamin, 2018: 374$375)$.

\section{Espaço e tempo. Performance e espetáculo}

O interior e o exterior de certo não são as únicas categorias benjaminianas para o espaço. Andrew Benjamin centra sua análise de "Nápoles" numa interpretação, arrisco dizer, um tanto ousada das ideias de espaço e tempo do autor. Para comentador, a interpenetração destas duas dimensões é que constitui a temporalidade benjaminiana. Nessa perspectiva, especial proeminência é dada à ideia de movimento. A fim de exemplificar dentro do próprio ensaio seu argumento, Andrew Benjamin faz referência ao café napolitano:

Os cafés são verdadeiros laboratórios desse grande processo de interpenetração. Neles, a vida não tem tempo de se estabelecer para se estagnar. São espaços abertos e insípidos, do gênero botequim de políticos (...). Cafés napolitanos são exíguos. $E$ praticamente impossível uma permanência mais longa. Uma xícara fervente de caffè espresso (...) despacha o freguês com uma saudação (Benjamin, 2011a: 145, grifos da pesquisadora).

\footnotetext{
${ }^{22}$ No original, para benefício do leitor: "an active dimension comes to define what is usually taken either as static or as complete" (Andrew Benjamin, 2005: 38).
} 
O comentador intriga-se com a afirmação de Benjamin - "É praticamente impossível uma permanência mais longa" - mas o que determina a duração desta permanência? Para Andrew Benjamin, é o movimento do corpo no espaço do café:

\begin{abstract}
Movimento vem a definir o modo pelo qual o espaço é tanto contrastado como trabalhado de dentro (...). O que delimita a duração da permanência tem a ver com a maneira pela qual o café é bebido. O café é pedido por gestos. Nápoles é caracterizada pela "língua dos gestos", ${ }^{23}$ (Die Gebärdensprache). O pedido da bebida, seu consumo e a passagem para fora do café, todos precisam ser entendidos no contexto da rítmica gestual. O espaço é posicionado - e, portanto, criado - por um ritmo particular em detrimento de outro. (...). O argumento de que "é praticamente impossível uma permanência mais longa", tem a ver, portanto, com o modo pelo qual o espaço do café é construído (Andrew Benjamin, 2005: 34-35, tradução da pesquisadora $)^{24}$.
\end{abstract}

Afirmo ser "ousada" a colocação do comentador por sua pretensão generalista, ao mesmo tempo que toma como objeto de reflexão exclusivamente o ensaio sobre Nápoles. Não obstante, inspira confiança na medida em que as concepções espaçotemporais benjaminianas de fato se imiscuem em tantos outros escritos seus ${ }^{25}$. Como afirma Keith, Benjamin

traça um foco analítico em direção à construção tanto da temporalidade como da espacialidade como estruturas de sensibilidade que apenas podem ser interrompidas e reveladas pela justaposição, súbitas (surreais) rupturas dos imperativos da narração das geografias e histórias do sujeito (Keith, 2003: 420, tradução e grifos da pesquisadora) ${ }^{26}$

Se Andrew Benjamin comenta a noção de espaço em "Nápoles" municiado dos conceitos de temporalidade e movimento, Gilloch traz outras importantes dimensões para a discussão, embasadas nas noções de "performance", “improvisação" e "espetáculo":

\footnotetext{
${ }^{23} \mathrm{Na}$ tradução brasileira, "pantomima" que, no teatro, diz respeito a um tipo de performance no qual uma história é representada exclusivamente através de gestos.

${ }^{24}$ No original, para benefício do leitor: “(...) movement comes to define the way in which space is both contrasted and then worked within (...). What delimits the length of stay has to do with the way coffee is drunk. Coffee is ordered by gestures. Naples is characterized by the "language of gestures" (Die Gebärdensprache). The ordering of the drink, its consumption and the passage out from the café, all need to be understood within the rhythm of the gesture. Space is positioned - and therefore created - by one particular rhythm rather than another. (...). The argument as to why it is "barely possible" to stay within the café for sustained period of time has to do therefore with the way the space of the café is constructed" (Andrew Benjamin, 2005: 34-35).

${ }^{25}$ Quiçá o excerto "Escavar e Lembrar" (Ausgraben und Erinnern) seja um dos escritos no qual a relação, ou melhor, interpenetração entre espaço e tempo seja mais evidente (Benjamin, 2011b: 227). Também nesse sentido, porém em relação aos escritos urbanos, é Infância em Berlim por volta de 1900 que deve ganhar mais atenção (Benjamin, 2011b).

${ }^{26}$ No original, para benefício do leitor: "Hence the plastic construction of the relations between time and space (Bullock and Jennings 1996, p. 499) draw an analytical focus towards the construction of both temporality and spatiality as structures of sensibility that can only de disrupted and revealed through juxtaposition, sudden (surreal) ruptures of the narrative imperatives of geographies and histories of the subject" (Keith, 2003: 420).
} 
A noção de espetáculo público é particularmente importante em Nápoles. O conceito de porosidade abarca improvisação e performance. A cidade é transformada em um teatro (...). Esta representação da configuração urbana como teatro e da vida social como drama e performance são facetas recorrentes, porém pouco desenvolvidas, dos escritos urbanos de Benjamin (Gilloch, 1996: 30, tradução da pesquisadora). ${ }^{27}$

Com efeito, logo no início do ensaio, ao comentar sobre a pobreza napolitana, Benjamin dá especial ênfase à performance dos mendicantes, como nota o item 4 da tabela: "Um mendigo jaz na rua, apoiado contra o meio fio, e agita, como quem se despede na estação ferroviária, o chapéu vazio" (Benjamin, 2011a: 137). A mesma sensibilidade à "performance" da pobreza pode ser vista em seu ensaio sobre "Moscou", no qual comenta:

A mendicância não é agressiva como na Europa meridional (...). Aqui existe uma corporação de moribundos (...). Longos discursos suplicantes tocam as pessoas. Eis um mendigo que dá início a um choro baixo e persistente toda vez que dele se aproxima alguém de quem espera obter alguma coisa (Benjamin, 2011a: 153).

Também ganham evidência as performances de vendedores e ambulantes (itens 14, 22, 24 e 25 da tabela). Por exemplo, comenta o autor sobre o caráter misterioso e espetacular de um vendedor de rua, em volta do qual se apinham clientes curiosos:

Um sujeito se acha numa caleça desatrelada em certa esquina. Pessoas se apinham
ao redor. A boleia está aberta, e o vendedor dela retira alguma coisa que não para de
apregoar. Antes que possa ser vista, desaparece num papelote colorido de rosa ou de
verde. Assim ele a ergue e num instante é vendida por poucos soldi. Com os
mesmos gestos misteriosos vai vendendo uma peça após a outra. Haverá bilhetes de
loteria nesse papel? Bolos com uma moeda em cada dez? O que torna as pessoas tão
ávidas e o homem tão inescrutável como o "Moograby" - Está vendendo pasta de
dente (Benjamin, 2001a: 142).

A representação do cenário urbano como teatro e da vida social como drama e performance, de fato são temas recorrentes nos ensaios urbanos de Benjamin, e pouco explorados, como comenta Gilloch. Mais uma vez, podemos nos remeter à capital da modernidade, a Paris do século XIX, como exemplo. As cadeiras dos cafés parisienses voltavam-se então para as novas e amplas ruas inauguradas por Georges-Eugène Haussmann - o que faziam os clientes se não observar o espetáculo da multidão, assim como o homem convalescente do conto de Edgar Alan Poe, tão caro à Benjamin? Quem sabe o espetáculo napolitano não é semente do drama parisiense benjaminiano. Relacionado diretamente à ideia de porosidade e improvisação (Gilloch, 1996), ele se dá nos mais variados espaços da cidade:

\footnotetext{
${ }^{27}$ No original, para benefício do leitor: The notion of public spectacle is particularly important in Naples. The concept of porosity embraces improvisation and performance. The city is transformed into a theatre (...). This representation of the urban setting as theatre and social life as drama and performance are recurrent though always underdeveloped facets of Benjamin's city writings (Gilloch, 1996, p. 30).
} 
Balcões, átrios, janelas, portões, escadas, telhados, são ao mesmo tempo palco e camarote. Mesmo a existência mais miserável é soberana no vago conhecimento de atuar em conjunto, em toda a perversão, numa cena de rua napolitana, que nunca se repete (Benjamin, 2011a: 139). 


\section{A criança e o brinquedo}

Finalmente, apresento o último tema de "Nápoles" apontado na tabela temática, a "experiência infantil". Ela é claramente foco de atenção de Benjamin, como demonstram os escritos de Infância em Berlim por volta de 1900 (2011a), suas Narrativas Radiofônicas (2015), e tantos outros ensaios.

Entre 1929 e 1932, Benjamin falava na rádio alemã "quase que regularmente" (Tiedemann, 2015) e tinha um programa voltado a crianças e jovens. Muitas das temáticas urbanas de Imagens do Pensamento ou Infância em Berlim são trabalhadas também nestas narrativas. Inclusive, uma delas trata sobre Nápoles (Benjamin, 2015: 217-226), abordando praticamente os mesmos pontos do ensaio de Imagens do Pensamento, porém com a narrativa adaptada ao público e ao meio radiofônico.

Em "Nápoles", a porosidade age em vários aspectos do universo infantil. Por um lado, a falta de fronteiras entre o público e privado, o interior e o exterior, leva as crianças a travarem rápido conhecimento com o sexo - tema que aparecerá também em dois escritos de Infância em Berlim, "O despertar do sexo" e "A despensa" (Benjamin, 2011a). Sobre a criança napolitana, o autor comenta:

Nos quarteirões super povoados, mesmo as crianças travam rapidamente conhecimento com o sexo. Mas, se em algum lugar seu aumento se torna devastador (...) não vão carecer de um parente mais próximo ou mais afastado. Uma vizinha aceita à sua mesa uma criança por prazo curto ou longo, e desse modo as famílias se interpenetram em relações, que podiam se equiparar à adoção (Benjamin, 2011a: 145).

Como já mencionei, o autor também dedica atenção aos brinquedos napolitanos, suas formas, cores e usos:

Isso [a porosidade] prossegue até nos brinquedos. Diluída e com pálidas cores do Kindle de Munique se acha a Madona nas paredes das casas. O menino que ela estende à sua frente como um cetro se encontra desse mesmo jeito, rígido, enfaixado, sem braço e sem perna, como um boneco de madeira nas lojas mais pobres de Santa Lucia. Com essa peça os pirralhos podem bater onde queiram (Benjamin, 2011a: 144-145).

O interesse do autor por brinquedos, jogos, livros infantis e miniaturas aparecerá em uma série de outros escritos ${ }^{28}$. $\mathrm{O}$ apreço de Benjamin por tais objetos não diz respeito apenas a um capricho de colecionador - para o autor, eles "concorrem para tornar o mundo mais inteligível” (Werneck, 2010).

\footnotetext{
${ }^{28}$ Por exemplo, os textos de "Reflexões sobre a criança, o brinquedo e a educação" (Benjamin, 2014), ou alguns escritos de Infância em Berlim (2001a), como "O jogo das letras", "O carrossel", "A caixa de costura", "Neuer Deutscher Jugendfreund", "Esconderijos”, dentre outros.
} 


\section{Considerações finais}

Este artigo teve duplo objetivo. Por um lado, procurei contribuir para a análise da obra benjaminiana no que diz respeito à produção do autor sobre o urbano. A escolha pelo trabalho com comentadores estrangeiros não foi aleatória, mas visou justamente trazer novas referências para aqueles que se interessam por este tão singular e ao mesmo tempo tão multifacetado autor.

O ensaio sobre Nápoles foi o escolhido para esta análise por ser apontado por comentadores como uma das origens do pensamento de Benjamin sobre o urbano. De fato, o autor introduz temas que serão observados e escrutinados em outros escritos seus e, principalmente, no projeto das Passagens. A construção de uma tabela temática almejou precisamente demonstrar que certas dimensões da ambiência urbana ganharão especial atenção do autor, em toda sua obra.

Tal procedimento pode parecer um intento deveras sistemático a ser aplicado no espólio de um autor conhecido por seus escritos ensaísticos e fragmentários, que objetivaram claramente escapar à disciplina sistemática da teoria tradicional. Parafraseando Michel Foucault, podemos pensar na obra de Benjamin como algo que se enrola em si mesmo; suas ideias e temas urbanos parecem sair de um dicionário de analogias. Como coloca Keith "O pensamento de Benjamin escapa a categorização disciplinar precisamente porque a categorização disciplinar é objeto do seu estudo" (Keith, 2003: 419, tradução da pesquisadora $)^{29}$. A observação deste comentador não poderia estar mais correta.

Por outro lado, noto que a profunda relação de Benjamin com as cidades pelas quais passou ou nas quais viveu deu origem a importantes reflexões, que possuem grandíssimo potencial analítico para os estudiosos da cidade contemporânea. Keith também está correto quando afirma que a ausência da obra do autor na literatura mainstream da sociologia ou antropologia urbanas é um erro. Procurei demonstrar alhures como há uma linhagem dos estudos urbanos que tomam por referência primordial ideias de Benjamin (Oliveira, 2017b) e, aqui, por meio da classificação temática de um de seus primeiros ensaios sobre a cidade, reforço meu argumento de que

\footnotetext{
${ }^{29}$ No original, para benefício do leitor: "Benjamin's thinking escapes disciplinary categorization precisely because disciplinary categorization is the object of its study" (Keith, 2003: 419).
} 
seus escritos urbanos devem ganhar maior evidência nos estudos de nossa contemporaneidade.

Vale ressaltar que Benjamin foi sensível a temáticas que hoje são bastante exploradas na sociologia ou antropologia urbanas. Neste artigo, remeto-me a duas - o crescente interesse pelos sentidos na investigação urbana, e a ideia do turismo e da transformação da tradição em mercadoria. Não obstante, a variedade de temas explorada pelo autor traz à tona as múltiplas facetas e dinâmicas de uma cidade, a serem enfrentadas por qualquer pesquisador. Mais importante, poder-se-ia afirmar que esta visão holística (por falta de melhor adjetivo) de Benjamin sobre o urbano é adquirida, paradoxalmente, não à "vol d'oiseau" - do alto, a contemplar a cidade como o oceano "a quebrar-se como as rochas" (Benjamin, 2011b: 56), mas sim em meio à multidão, à vida das ruas. Caberia justamente lembrar da colocação de Hélio R. Silva: "A cidade é percorrida e é pensada apenas pelo transeunte que ela própria engloba. A cidade é vista do interior de suas entranhas. O desenho à vol d'oiseau é tentativa de levitar sobre o que só ganha sentido na pedestre circulação" (Silva, 2009: 174).

Flâneur, fisiognomonista da cidade, e, acrescento, etnógrafo urbano, Benjamin certamente aprendeu a lição de estranhar o familiar, e ao mesmo tempo afetar-se por ele.

\section{REFERÊNCIAS}

BASSETT, Keith. Walking as an aesthetic practice and a critical tool: Some psychogeographic experiments. Journal of Geography in Higher Education, n. 28, pp. 397-410, 2007.

BENJAMIN, Andrew. Porosity At The Edge: Working through Walter Benjamin's "Naples". Architectural Theory Review, n. 1, 2005, pp. 33-43.

BENJAMIN, Walter. Obras escolhidas II: Rua de mão única. $1^{\text {a }}$ ed. São Paulo: Brasiliense, 2011a.

. Obras escolhidas III: Charles Baudelaire um lírico no auge do capitalismo. $1^{\text {a }}$ ed. São Paulo: Brasiliense, 2011 b. 
- A hora das crianças: narrativas radiofônicas de Walter Benjamin. Riod e Janeiro: NAU editora, 2015.

Passagens. Belo Horizonte: Editora UFMG, 2018.

BENJAMIN, Walter; SCHOLEM, Gershom; ADORNO, Theodor. The correspondence of Walter Benjamin, 1910-1940. Chicago: The Univerty of Chicago Press, 1994.

BOLLE, Willi. Fisiognomia da metrópole moderna: representação da história em Walter Benjamin. São Paulo: Edusp, 1994.

A metrópole como hipertexto: a ensaística constelacional do Projeto das Passagens, de Walter Benjamin”. In: MACHADO, Carlos Eduardo J. et al (org.). Walter Benjamin. Experiência histórica e imagens dialéticas. São Paulo: Editora Unesp, 2015, pp. 85-98.

BORCHARD, Kurt. Between a hard rock and postmodernism: opening the hard rock hotel and casino. Journal of Contemporary Ethnography, v. 27, 1998, pp. 242-269.

BUCK-MORSS, Susan. Dialética do olhar: Walter Benjamin e o projeto das passagens. Belo Horizonte: UFMG; Chapecó: Argos, 2002.

COURTINE, Jean Jacques. Decifrar o corpo: pensar com Foucault. Petrópolis: Editora Vozes, 2013.

ECKERT, Cornélia; ROCHA, Ana Luiza Carvalho da. Etnografia de rua: Estudo de antropologia urbana. Iluminuras, v. 4, 2003.

FORTUNA, Carlos. Identidades, percursos, paisagens culturais: estudos sociológicos de cultura urbana. Coimbra: Imprensa da Universidade de Coimbra, 2013.

GILLOCH, Graemme. Myth \& metropolis: Walter Benjamin and the city. Cambridge: Polity Press, 1996.

GOTTSCHALK, Simon. Ethnographic fragments in postmodern spaces. Journal of Contemporary Ethnography, v. 24, 1995, pp. 195-228.

JENKS, Chris; NEVES, Tiago. A walk on the wild side: urban ethnography meets the flâneur. Journal for Cultural Research, v. 4, 2000, pp. 1-17.

KEITH, Michael. Walter Benjamin, urban studies and the narratives of city life. In: BRIDGE, G; WATSON, S. A Companion to the city. Oxford: Blackwell Publishing Ltd, 2003, pp. 410-429. 
MACHADO, Carlos Eduardo. "Walter Benjamin: "montagem literária”, crítica à ideia de progresso, história e tempo messiânico. In: MACHADO, Carlos Eduardo J. et al (org.). Walter Benjamin. Experiência histórica e imagens dialéticas. São Paulo: Editora Unesp, 2015, pp. 131-144.

MYERS, Misha. Walking Again Lively: Towards an Ambulant and Conversive Methodology of Performance and Research. Mobilities, v.6, n. 2, 2011, pp. 183-201.

OLIVEIRA, Beatriz S.C. Walter Benjamin, leitor das cidades: linhagens da antropologia urbana. 2017. Dissertação (Mestrado em Ciências Sociais) - Pontifícia Universidade Católica de São Paulo, São Paulo, 2017a.

. Linhagens benjaminianas do pensamento etnográfico. Revista BIB, n. 81, 2017b, pp. 42-65.

PINK, Sarah. An urban tour. The sensory sociality of ethnographic place-making. Ethnography, v. 9, n. 2, 2008.

POE, Edgar Allan. "O homem da multidão". In: BAUDELAIRE, C. O pintor da vida moderna. Belo Horizonte: Editora Autêntica, 2010, pp. 91-102.

ROUANET, Sérgio Paulo. As razões do iluminismo. São Paulo: Companhia das Letras, 1987.

SILVA, Hélio R. A situação etnográfica: andar e ver. Horizontes Antropológicos, v. 15, 2009, pp. 171-188.

SILVANO, Filomena P. Cuando las ciudades se transforman en paisajes: representación, fragmentación e idealización del espacio urbano. Zainak, n. 31, pp. 419429, 2009.

SONTAG, Susan. Sob o signo de saturno. São Paulo: L \& PM Editores, 1986.

SOUKUP, Charles. The postmodern ethnographic flaneur and the study of hypermediated everyday life. Journal of Contemporary Ethnography, v. 42, 2013, pp. 226254.

TIEDEMANN, Rolf. "Nota à edição alemã". In: BENJAMIN, Walter. A hora das crianças. Narrativas radiofônicas. Rio de Janeiro: NAU Editora, 2015.

WERNECK, Mariza Martins Furquim. Alguns temas em Walter Benjamin. Ponto-eVirgula Revista de Ciências Sociais, v. 8, 2010, pp. 232-241 
WIZISLA, Erdmunt. "Construído com astúcia. Um modelo para o modo de escrever de Walter Benjamin". In: MACHADO, Carlos Eduardo J. et al (org.). Walter Benjamin. Experiência histórica e imagens dialéticas. São Paulo: Editora Unesp, 2015, pp. 13-22.

Recebido: $02 / 06 / 2020$

Aprovado: $04 / 09 / 2020$ 